\title{
Solar distillation of impure water from four different water sources under the southwestern Nigerian climate
}

\author{
Saheed A. Adio ${ }^{1}$, Emmanuel A. Osowade ${ }^{1}$, Adam O. Muritala ${ }^{1}$, Adebayo A. Fadairo ${ }^{1}$, \\ Kamar T. Oladepo ${ }^{2}$, Surajudeen O. Obayopo ${ }^{1}$, and Paul O. Fase ${ }^{1}$ \\ ${ }^{1}$ Thermofluids Research Group, Department of Mechanical Engineering, \\ Obafemi Awolowo University, Ile-Ife, Nigeria \\ ${ }^{2}$ Water Engineering Research Laboratory, Department of Civil Engineering, \\ Obafemi Awolowo University, Ile-Ife, Nigeria
}

Correspondence: Saheed A. Adio (adiosa@ oauife.edu.ng) and Adam O. Muritala (muriadam@gmail.com)

Received: 17 February 2020 - Discussion started: 11 May 2020

Revised: 9 December 2020 - Accepted: 21 December 2020 - Published: 12 February 2021

\begin{abstract}
The enormous problems caused by the scarcity of potable water and the transmission of waterborne diseases such as cholera, dracunculiasis, hepatitis, typhoid and filariasis in some parts of Nigeria have created a public health concern. Every day thousands of lives are lost due to contact with waterborne diseases. The insufficient medical resources available in developing countries are deployed towards the treatment of waterborne diseases that can easily be avoided if potable water can be made available. This study seeks to investigate the purification of four different water samples (namely water from flowing rivers, freshly dug well or groundwater, rainwater from the rooftops and heavily polluted dirty water) consumed by the people in the local community using a solar desalination method. A single basin solar still was constructed, and experimental studies were carried out to determine the influence of solar insolation and temperature variations on the yield of the distillate for both the passive and active solar stills tested. The quality of the distillate was tested by measuring the total dissolved solid (TDS) and electrical conductivity (EC) and later comparing it to the World Health Organization (WHO) standard for drinkable water. The values obtained after desalination fall within the acceptable/tolerable range for TDS and EC, in accordance with the WHO standard for drinkable water. This analysis provides an indigenous distillation method to enhance the production of drinkable water at a low cost.
\end{abstract}

\section{Introduction}

Naturally, most water exists in a polluted or non-purified form with lots of microorganisms capable of causing cholera, dracunculiasis, hepatitis, typhoid, filariasis and so on (Rab et al., 1997). Most times, the water consumed by people in subSaharan Africa, and Nigeria specifically, is sourced from a flowing river, freshly dug well or groundwater, run-off water from rusted iron or asbestos rooftops and heavily polluted water (dirty stagnant surface water) without any further purification (Onwujekwe et al., 2009; Smith et al., 2004). The drinking of water from these sources without further purification poses health challenges to different rural settlements in this category. For instance, rainwater collected from rusted rooftops is not only dirty but may be harmful (Abbasi and Abbasi, 2011; Bennamoun et al., 2013; González, 2012; Lye, 2009; Meera and Ahammed, 2006; Mendez et al., 2010; Norman et al., 2019; University of Texas at Austin, 2011). Many water purification processes exist, including desalination technology with over 10000 desalination plants in the world having a total desalted water capacity of over 5 billion gallons (18.93 million cubic metres) a day. Saudi Arabia is the largest user of desalination, with about $25 \%$ of the world's capacity, and the United States is the second largest user, with $10 \%$ of their water being desalinated (Cengel and Boles, 2015). Vapour compression distillation, reverse osmosis and electrodialysis using electricity generated from coal and fossil fuel combustion as input energy are examples of 
desalination systems; however, they have been found to be very expensive and basically unsustainable due to the amount and cost of energy required to carry out the processes. Also, the hazardous greenhouse gas emissions released during desalination processes using electricity from fossil fuel combustion cause climate change and ozone layer depletion. This has caused the rise in global temperatures and the melting of glaciers and ice sheets faced by many countries of the world (Goosen et al., 2012; Kalogirou, 2014, 2011). Currently, solar desalination stands as one of the most efficient, effective and more economical water purification systems in terms of low running cost, long lifespan and minimal environmental pollution when compared with other types of water purification systems, especially for rural communities. This can be attributed to the free and abundant gift of the Sun and its renewability (C. Elango et al., 2015; Sampathkumar et al., 2010). The device used for performing this purpose is a solar still. It operates similarly to the natural hydrologic cycle of evaporation and condensation. Among the different types of solar stills, the single basin single slope still type occupied the best place due to its simplicity in design and operation. The heat from the Sun evaporates the pure water from the impure, brackish or saline water collected in the still basin covered by a glass, leaving behind the microorganisms and other contaminants in the basin. The evaporated water condenses on the inner surface of the glass, and the condensed liquid flows down freely beneath the inclined cover to a vshaped trough/water channel at the bottom of the still, where it is collected for human consumption (Tiwari and Tiwari, 2006; Tiwari et al., 2009).

Solar stills can be classified into two types, namely active and passive. A passive solar still receives solar radiation directly from the Sun into the water in the basin. The Sun is the only source of energy responsible for raising the water temperature for evaporation. An active solar still utilizes more than one energy source (other than the Sun) for water distillation (El-Sebaii, 2004; Sivakumar and Sundaram, 2013). The extra thermal energy is supplied through an external means for better performance. The temperature difference between the water in the basin and the inner surface of the glass cover, the water depth in the basin, the material of the basin and the black body absorber, the wind velocity, the insolation intensity, the ambient temperature and the inclination angle of the glass have all been found to affect the solar still productivity (T. Elango et al., 2015; Sampathkumar et al., 2010; Tiwari and Tiwari, 2005). Solar distillation is not a new technology and neither is the method/structure of the solar still (that is, single slope conventional type) adopted in this research. However, the experimental design and the set-up are location specific. This determines the angle of tilts (that is, the orientation and placement) of the solar still to better capture the solar radiation from the Sun. The tilt angle of the glass condenser significantly affects the output of the solar still. Many authors have worked on the choice of optimum tilt angle for the glass cover. Some others (Chinnery, 1971; Elsayed, 1989;
Felske, 1978; Heywood, 1971; Khorasanizadeh et al., 2014; Qiu and Riffat, 2003; Stanciu and Stanciu, 2014) found a latitude plus $10^{\circ}$ tilt angle allowed for better solar still performance. In the case of this study, carried out on $7.5175^{\circ} \mathrm{N}$ latitude, the glass cover tilt angle was kept at $17^{\circ} 52^{\prime \prime}$, (that is $7.5175^{\circ} \mathrm{N}$ latitude plus $10^{\circ}$ ).

The performance of a solar still (that is, the rate of evaporation of the impure water) is usually expressed as the amount of distilled water produced by the basin area in a day (Kabeel et al., 2014a). This performance is strongly enhanced by the large temperature difference between the surface of the water in the basin (serving as the evaporator) and the inner glass cover surface (serving as the condenser; Asbik et al., 2016; C. Elango et al., 2015; T. Elango et al., 2015; Kabeel et al., 2014b, 2016; Manokar et al., 2014; Rahbar et al., 2015; Sampathkumar et al., 2010; Sharshir et al., 2016; Sivakumar and Sundaram, 2013; Taghvaei et al., 2015). This quantity produced varies largely with the available solar radiation, cloud conditions, atmospheric humidity, wind speed and ambient temperature, which are meteorological parameters that cannot be altered by human beings. Other design parameters that affect productivity are the orientation of the still, depth of the water, inclination of the glass cover, slopes of the cover, insulation materials, area of absorber plate, inlet temperature of the water and the temperature difference between the glass cover and the basin water (Sivakumar and Sundaram, 2013).

The salinity of any water strongly depends on the electrical conductivity (EC) of the water. The lower the EC of the water, the purer the water. Low levels of salts are found naturally in waterways and are important for plants and animals to grow. High salt levels in freshwater causes problems for aquatic ecosystems and cause complications in human organs.

Apart from the coastal region of Nigeria where people are forced by circumstance to process salty water for domestic use, the commonly available water in some rural areas is not pure due to dissolved organic and inorganic materials. In some locations (e.g. Ile-Ife, Osun state; $7.4905^{\circ} \mathrm{N}$, $4.5521^{\circ} \mathrm{E}$ ) the salt content of water collected from dug wells, rivers and even boreholes is very high and requires treatment. Hence, an affordable, yet very efficient, process that requires little or no technical know-how and maintenance for the purification of water from these sources will be a welcome idea in such rural settlements. Therefore, the main objective of this study is to design, construct and test a solar desalinating plant made with locally sourced materials for the purification of water from the following sources: rainwater, freshly dug well water, river water and heavily polluted water which are peculiar to the site in which this research is carried out and to most rural areas in Nigeria.

The effects of the solar radiation intensity, inner glass surface temperature and the absorber plate temperature, as they affect the hourly distillate yield, were examined for both passive and active solar still configurations. The performance and efficiency of the solar desalinating plant was evaluated 
based on its distillate yield. Finally, the water samples were tested after desalination to ascertain the suitability of the water for drinking purposes, based on the WHO standard for drinking water. This is with a view to mitigate the widespread waterborne diseases in rural settlements in Nigeria as a result of indiscriminate drinking of untreated or impure water due to the unavailability of drinkable water.

\section{Materials and methods}

This research was carried out at the Department of Mechanical Engineering, Obafemi Awolowo University, Nigeria $\left(7.5175^{\circ} \mathrm{N}, 4.5270^{\circ} \mathrm{E}\right)$, between the months of July and September. A total of two sets of experiments were prepared, namely the conventional solar still (CSS) and the conventional solar still with a flat plate collector (CSS-FPC). For the CSS-FPC type, a pressure valve was used to prevent water inlet into the still until the desired water temperature and pressure was reached to sufficiently force the pressure valve open to allow the flow of water to the still basin from the flat plate solar collector.

In this experimental work, the CSS was fabricated with a square stainless-steel sheet of $1 \mathrm{~m}^{2}$ and $2 \mathrm{~mm}$ thickness. The surface area of the solar collector that receives the heat from the Sun measures $1 \mathrm{~m}^{2}$. The solar still basin was coated with black paint in order to increase the solar radiation absorptivity of the still. The black body absorbs the heat energy from the Sun to raise the temperature and the vapour pressure of the water (Cowling, 1950; Manabe and Wetherald, 1967). Figure 1 shows the isometric and exploded view of the experimental set-up, while Fig. 2 shows a photograph of the experimental set-up. A single slope CSS was used because it is a good recipient of higher levels of solar radiation at both low and high latitude stations compared to its doublesloped counterpart (Sivakumar and Sundaram, 2013). Stainless steel was used to construct the basin principally due to its higher heat-retaining capacity and higher resistance to corrosion that could further contribute to the water salinity. The CSS exterior walls (the sides and the bottom) were thermally insulated using $5 \mathrm{~cm}$ fibreglass to prevent heat energy loss from the solar still to the surroundings. Silicon sealant was used to prevent water leakage within the system and to create an airtight environment in the interior.

The solar still was covered with a condensing glass with $5 \mathrm{~mm}$ thickness. The glass selected was a tempered glass of high tensile strength capable of withstanding high solar radiation intensity and a wind and rain load with very low solar reflectivity (El-Samadony et al., 2016). Morad et al. (2015) showed that increasing the glass cover thickness reduces the amount of solar radiation that passes through it into the air gap and then to the basin water and, hence, reduces the solar sill (SS) thermal retention ability and efficiency as the glass cover thickness increases. The glass inclination is one of the major parameters that determines the CSS performance.
SS productivity was found to increase with a decrease in glass inclination (Bahadori and Edlin, 1973; Garg and Mann, 1976). In the present experiment, the tilt angle of the glass cover was kept at $17^{\circ} 52^{\prime \prime}$; that is, the latitude, $\varnothing$ of the research location $\left(7.5175^{\circ} \mathrm{N}\right)$ plus $10^{\circ}$ (Chinnery, 1971; Elsayed, 1989; Felske, 1978; Heywood, 1971; Khorasanizadeh et al., 2014; Qiu and Riffat, 2003; Stanciu and Stanciu, 2014). A float valve was used to maintain a constant water level in the basin as the water flows from either the storage tank or the flat plate collector. Water productivity has been found to be inversely proportional to the water depth (C. Elango et al., 2015; T. Elango et al., 2015; Kabeel et al., 2014a, 2012; Manokar et al., 2014; Muftah et al., 2014; Nafey et al., 2000). Also, a depth of $5 \mathrm{~cm}$ was found to be the optimum water depth for an improved SS performance, according to Kabeel et al. (2014a). In addition, the higher the distance between the glass cover and the basin's water surface, the more energy and time are required for the vapour to travel to the inner glass surface (Tiwari and Tiwari, 2005, 2008; Tiwari et al., 1994). Hence, the gap was reduced to $2 \mathrm{~cm}$.

\subsection{Experimental design}

A total of four different water samples (rainwater, freshly dug well water, river water and heavily polluted water) commonly consumed by people in rural settlements in Nigeria due to the unavailability of clean drinkable water were selected for the purpose of this research. The water from these sources has been found to be dirty and unhygienic for human consumption (Onwujekwe et al., 2009; Smith et al., 2004). The villagers, even passers-by, have their bath, urinate, defecate and even dispose of their refuse or dirt in the river water and the heavily polluted water. Following the solar still design and set-up above, the experiments were conducted for a period of $30 \mathrm{~d}$ between 08:00 local time (LT; hereinafter, all times are shown in local time) and 18:00, while readings were taken on an hourly basis. A single water sample was chosen for each day and was filled into the solar still basin to the required depth $(5 \mathrm{~cm}$, as mentioned above). The basin was subsequently tilted to an angle of $17^{\circ} 52^{\prime \prime}$, based on the geographical location of the research. The experimental set-up was left outside in the Sun to run between 08:00 and 18:00 daily. During this period, the heat from the Sun evaporates the water in the basin and later condenses on the inner surface of the glass, which is later channelled and collected. The temperature of the inner surface of the glass (condensing surface), the outer surface of the glass, absorber plate (evaporating surface) of the solar still, basin water temperature and temperature of the glass of the flat plate collector were measured and recorded intermittently on an hourly basis through a data logger while the experiment was ongoing. A total of five pieces of Copper/Constantan thermocouples (Type T) with temperature read-out were strategically mounted on different parts of the experimental set-up to measure temperatures at specific locations. Also, the most important meteoro- 


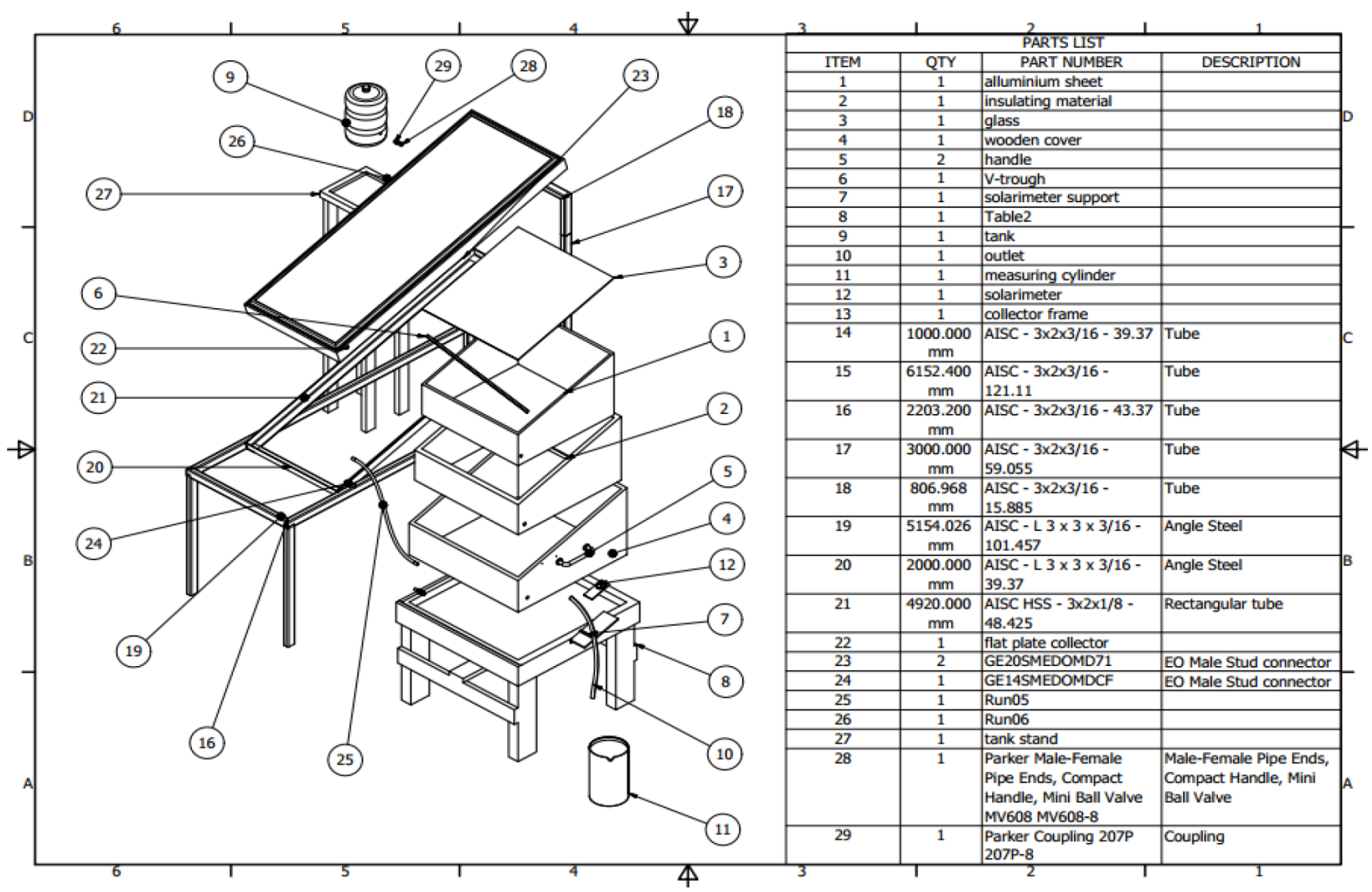

Figure 1. Isometric diagram and exploded view of the experimental set-up.

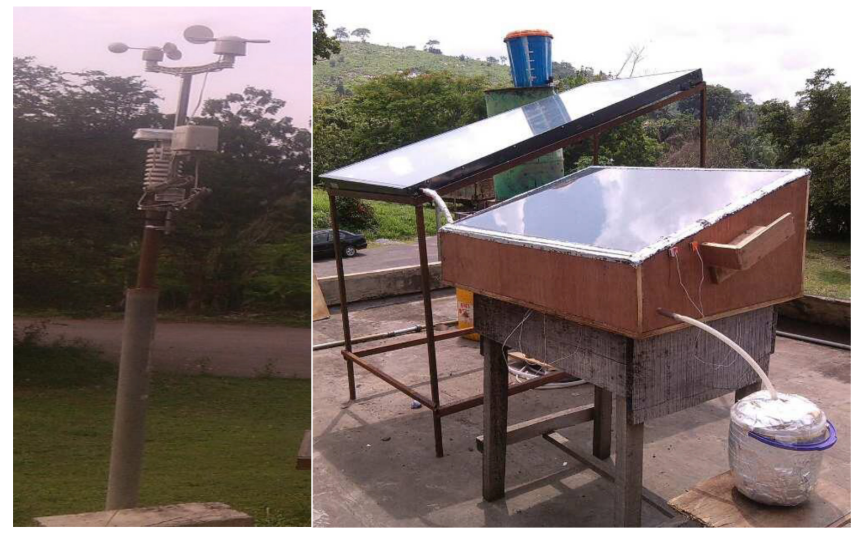

Figure 2. Experimental set-up of solar still coupled with flat plate collector.

logical parameters for the efficient performance of the CSS, such as solar radiation, ambient temperature and wind velocity, were subsequently measured and recorded. By the law of nature, these parameters cannot be controlled/altered; however, they were measured using a weather station positioned at the research location (Fig. 2). A transmitter was incorporated into the weather station. This was used to download and record the necessary meteorological parameters such as the amount of rainfall, ambient temperature, relative humidity, wind velocity and luminous intensity. Dust deposition and shade coverage on the glass surface reduces the transmittance power of the solar radiation, which could affect the distillate yield and the efficiency of the solar still. Hence, these were controlled by placing the experimental set-up at a height in which there was a clean environment, i.e. a little above the ground and cleared of anything that could constitute shade coverage, and the glass surface also was cleaned intermittently using a wet towel.

The basin was washed and made ready for another water sample after each experiment. These experiments were conducted for both the conventional and the single slope solar still with flat plate collector following the same steps discussed above.

\subsection{Performance evaluation}

The TDS in the water sample was measured using a digital conductivity meter by Mettler Toledo with $\pm 0.5 \%$ conductivity accuracy. The digital meter was used to measure both the TDS and the EC. It consists of a mode which is usually interchanged/switched when either the TDS or the EC mea- 
surement is required. This digital meter consists of a probe. For each time that each water sample was to be tested, the probe was immersed into the water sample up to the maximum immersion level advised by the manufacturer after the protective cap was removed, while the temperature of the water sample was maintained at room temperature. The water sample was thoroughly agitated to dislodge air bubbles and evenly distribute the particulate matter present in the water. The TDS and the EC level for the sample were taken after the reading stabilized. After each measurement, the probe was thoroughly cleansed, as prescribed, in order to eliminate the interference of the previous sample particle with the current sample. The digital meter also displays the temperature of the water sample being measured. The reading gives us the salinity estimate of the produced fresh water from the solar desalination unit.

The percentage reduction in TDS and EC was calculated using Eq. (1) as follows:

$\%$ Reduction $=\frac{P_{\mathrm{b}}-P_{\mathrm{a}}}{P_{\mathrm{b}}} \times 100 \%$,

where $P$ is the parameter under consideration (TDS or EC). Subscripts $\mathrm{a}$ and $\mathrm{b}$ represent after and before, respectively.

The solar still instantaneous efficiency, $\epsilon_{\mathrm{i}}$, was calculated using Eq. (2) as follows:

$\epsilon_{\mathrm{i}}=\frac{M \times h_{\mathrm{fg}}}{A \times I \times \Delta t}$,

where $M$ is the mass of the desalinated water at the output, $h_{\mathrm{fg}}$ is the latent heat of vaporization of the fluid, $A$ is the area of the flat plate collector $\left(1 \mathrm{~m}^{2}\right), I$ is the average solar irradiation for the time under consideration, and $\Delta t$ is the time under consideration (usually $1 \mathrm{~h}$ ).

Also, the daily production efficiency, $\epsilon_{\mathrm{d}}$, of the solar still system was calculated using Eq. (3) as follows:

$\epsilon_{\mathrm{d}}=\frac{\sum P_{\mathrm{h}} \times h_{\mathrm{fg}, \mathrm{da}}}{\left(C A_{\mathrm{a}} \times \sum I\right) \Delta t}$,

where $P_{\mathrm{h}}$ is the distillate productivity per hour, $A_{\mathrm{a}}$ is the absorber area, $C$ is the concentration ratio that is $A_{\text {ap }} / A_{\mathrm{a}}, A_{\text {ap }}$ is the aperture area, and $h_{\mathrm{fg}, \mathrm{da}}$ is the latent heat of vaporization daily average.

\section{Results and discussion}

Experiments were conducted for a period of $30 \mathrm{~d}$ between 08:00 and 18:00, while readings were taken on an hourly basis.

\subsection{Solar radiation and temperature variations in solar still}

Solar radiation is the radiant energy emitted and deposited by the Sun in an area at every second from a nuclear fusion reaction that creates electromagnetic energy with a temperature of about $5800 \mathrm{~K}$. It is one of the most important factors that determines the solar still productivity (Sharshir et al., 2016). Figure $3 \mathrm{a}-\mathrm{d}$ show the variation in solar radiation intensity, ambient temperature, glass temperature, absorber plate temperature and water temperature with the time for some randomly selected days. The graphs and results for other days shared some similarities. It was observed that the temperature kept increasing until a maximum point at around 15:00 in the afternoon for all days of the experiment. This is due to a consistent daily increase in the solar radiation intensity until 15:00 in the afternoon. The temperatures began to drop as soon as the solar radiation intensity started dropping and vice versa. This shows that the solar radiation intensity determines the temperatures of the elements in the still. It is also observed that the ambient temperature is always lower than all other temperatures for all days of the experiments in the research location. The solar radiation was maximum on the first day of the experiment, with an intensity of about $1128 \mathrm{~W} \mathrm{~m}^{-2}$ at 15:00 in the afternoon, and the lowest value obtained was $27.2 \mathrm{~W} \mathrm{~m}^{-2}$ on the second day of the experiment at 07:00 in the morning. The solar radiation intensity was measured with an Eppley precision spectral pyranometer (PSP), with an accuracy of $\pm 0.5 \%$ from 0 to $2800 \mathrm{~W} \mathrm{~m}^{-2}$.

It was observed that the evaporation rate and, consequently, the distillate yield increased as a result of an increase in the temperature difference between the temperature of the inner surface of the glass (condenser) and the temperature of the absorber plate (evaporator). From the graphs in Fig. 4, it can be seen that the glass temperatures are far lower than the temperature of the water. The minimum condensation glass temperature obtained was $25^{\circ} \mathrm{C}$, and the maximum was $40^{\circ} \mathrm{C}$. The wind speed of the environment at the moment under consideration affects the rate of condensation by the glass. The faster the wind speed, the faster the vapour loses its latent heat of vaporization to the surroundings. The increased wind speed yields a rapid drop in the condensing glass temperature and, hence, a wide temperature difference between the condensing glass and water. This enhanced the heat transfer performance and, hence, the distillate yields because the heat transfer rate is directly proportional to temperature difference. This is in good agreement with some similar past studies (El-Sebai, 2000, 2004; Stonebraker et al., 2010; Winfred Rufuss et al., 2017).

The temperature increase in the absorber shows that the absorber and the black body material are good absorbers and retainers of heat. This property was responsible for evaporation, even in off-peak periods when there was no sunlight and little or no solar irradiance. The stored heat in the black body raised the temperature of the water in the basin and, with the corresponding saturation pressure, evaporation occurs. The maximum temperature obtained for the absorber was $63^{\circ} \mathrm{C}$. 


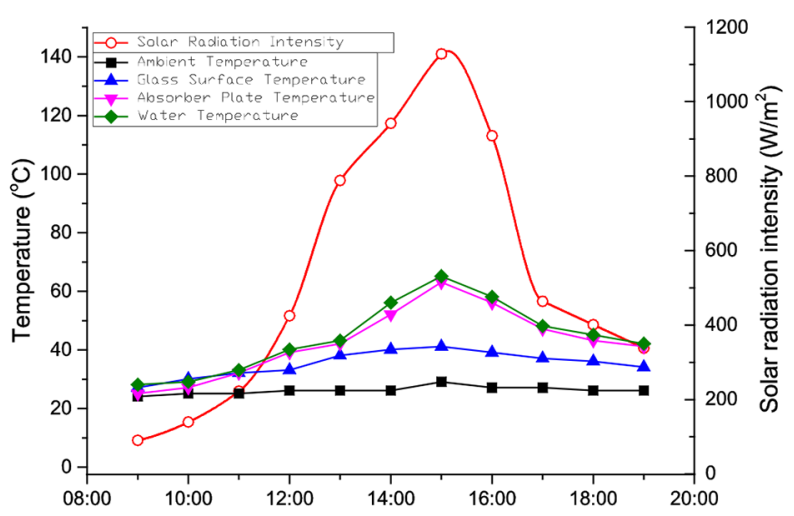

(a)

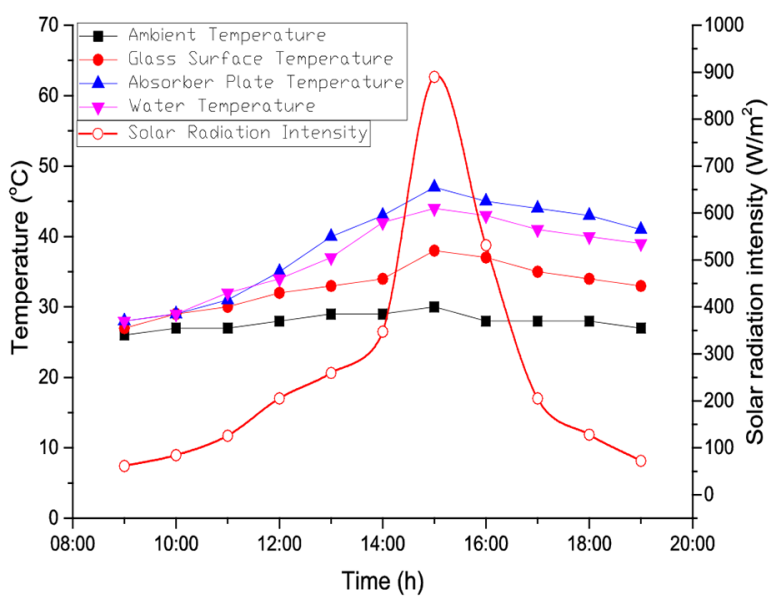

(c)

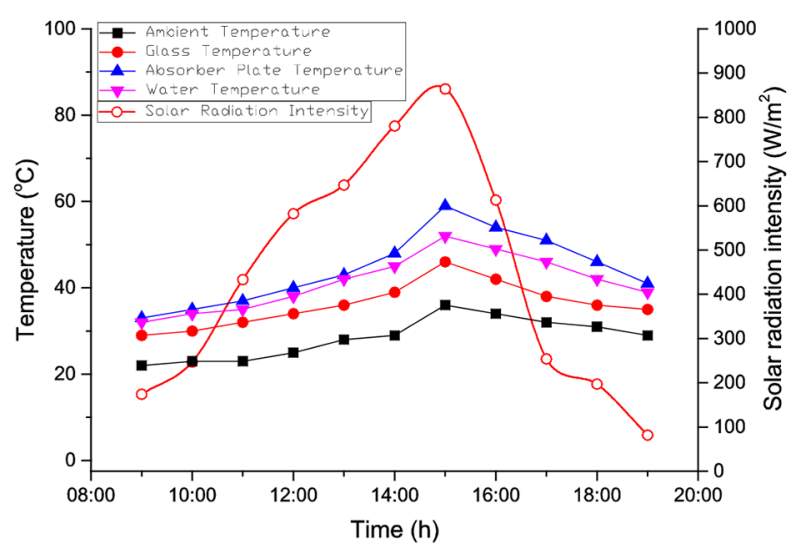

(b)

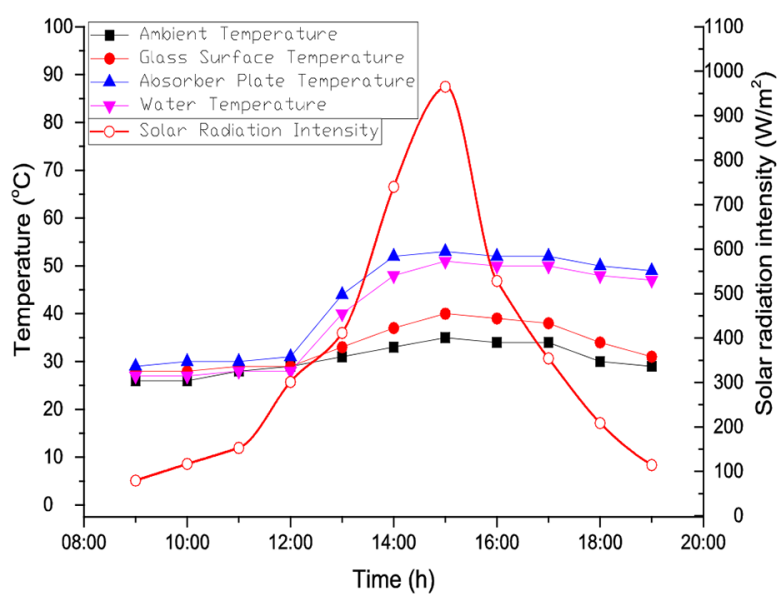

(d)

Figure 3. Daily temperature variation with solar radiation intensity. (a) Day 1, (b) day 3, (c) day 6 and (d) day 8.

\subsection{Effect of temperature variation on distillate yield}

Figure $4 \mathrm{a}-\mathrm{d}$ show the effect of temperature variation on distillate yield. Figure $4 \mathrm{a}$ and d give the distillate yield for the active solar still, while Fig. $4 \mathrm{~b}$ and c represent the distillate yield for the passive still. The graphs also justify that the temperature difference (that is, the difference between the glass cover and absorber plate temperatures) is the major factor responsible for evaporation. This trend was also observed by several authors (Ahsan et al., 2013; Ali et al., 2019; Edeoja et al., 2015; Kumar and Bai, 2008; Murugavel et al., 2010; Onyegegbu, 1986; Ozuomba et al., 2017; Sathyamurthy et al., 2015). Preheating the feed water to the solar still basin plays an important role in increasing the productivity of the still (Ahmadi et al., 2017; Badran and Abu-khader, 2007; Delgado-Torres et al., 2007; Kalogirou et al., 2016). Comparatively, a huge distillate yield was experienced when the flat plate collector was used on days $8,1,9$ and 2 , as shown in Fig. 6a and b. The solar still was used alone, without the flat plate collector, in the remaining days. It was observed that the continuous deposition of hot water into the basin from the flat plate collector resulted in higher production rates in all operation periods and mainly between 14:00-16:00 daily. This is due to higher internal convective, evaporative and radiative heat transfer from the water to the glass cover as the preheated water from the flat plate solar collector is deposited to the basin. Higher temperature differences were observed in the solar still with the flat plate collector, compared to that of no flat plate collector, throughout the working hours and under all conditions of the experiment. 


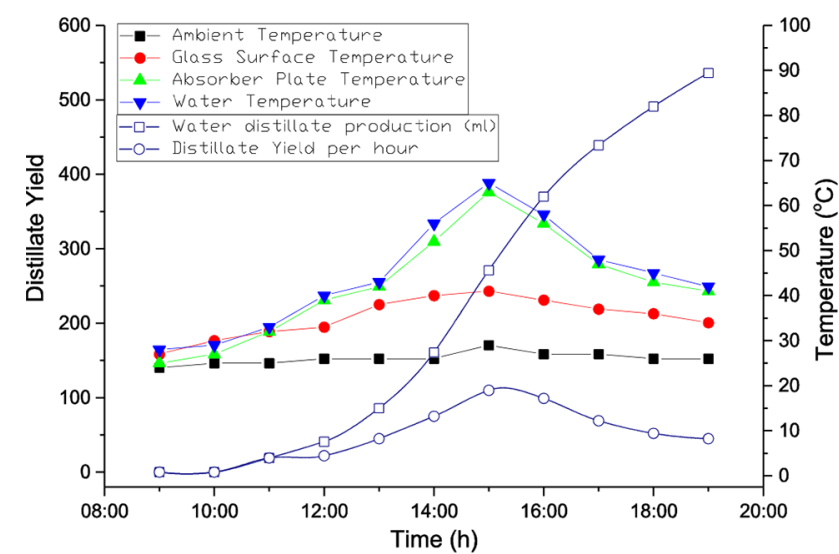

(a)

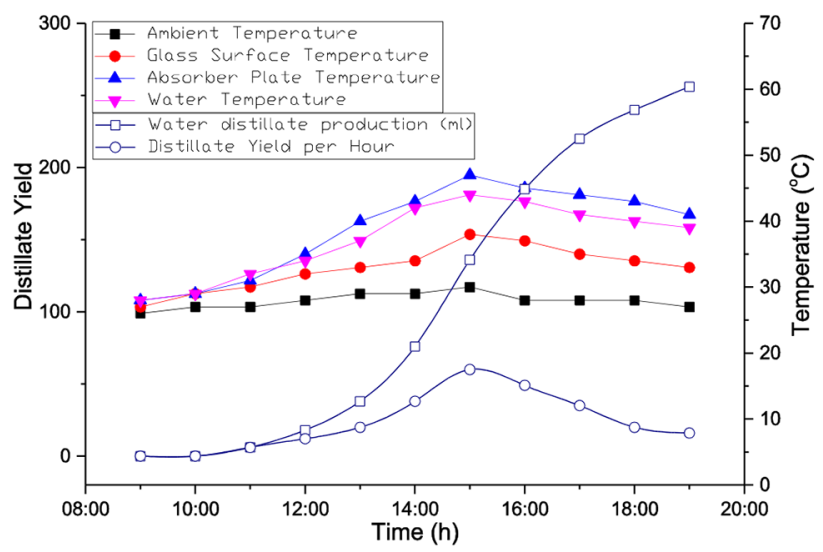

(c)

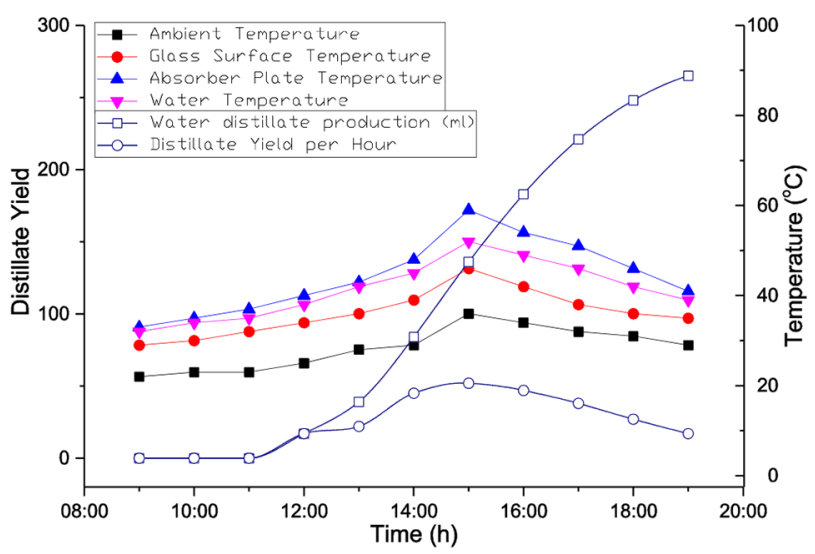

(b)

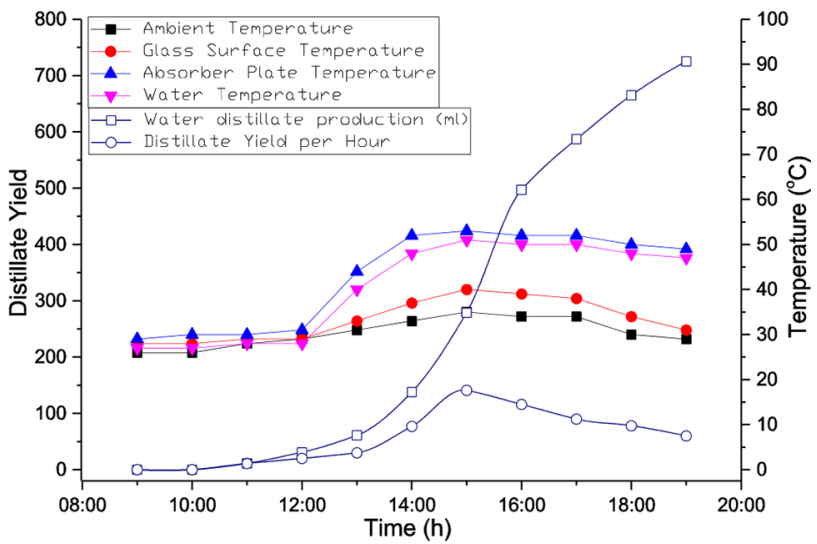

(d)

Figure 4. Influence of temperature on distillate yield. (a) Day 1, (b) day 3, (c) day 6, and (d) day 8.

\subsection{Effect of solar radiation on distillate yield}

Figure $5 \mathrm{a}-\mathrm{d}$ show the variation in solar radiation intensity and the distillate yield with time. Like the temperatures, the solar radiation intensity had a similar effect on the distillate yield. However, the differences between the effects with and without the flat plate collector cannot be easily detected using the solar radiation intensity curve alone. The temperature curves clearly show the differences between the glass temperature and the water temperatures and their consequential effects on the solar still productivity. Furthermore, the graphs (Fig. 5a-d) clearly indicate that the incident solar radiation strongly determines the increase in the still productivity.

\subsection{Cumulative distillate yield and the hourly distillate yield}

Figure $6 \mathrm{a}$ and $\mathrm{b}$ present the cumulative distillate yield and the distillate yield per hour for the $9 \mathrm{~d}$, respectively. The graphs clearly show the significant differences between the cumulative yield and the distillate yield per hour of the still with the flat plate collector and the ones without the flat plate collector. There is significant cumulative distillate yield on day 8 not only because of the second-largest solar radiation intensity recorded for the day $\left(965 \mathrm{~W} \mathrm{~m}^{-2}\right)$ but also because of the comparatively huge temperature difference between the glass cover (condensation surface) and the water in the basin and the consistently higher solar radiation intensity recorded for the other hours of the day. As discussed earlier, the variations observed in the distillate yield are due to the condensation glass-water temperature difference, wind speed variations and relative humidity of the research location per hour. The content of the polluted/saline water and the extent to which the water is polluted also affects the evaporation rates and, hence, the solar still productivity because the presence of impurities increases the boiling point of a fluid (or any 
Table 1. Water analyses results before and after desalination.

\begin{tabular}{lcr}
\hline Water sample & \multicolumn{2}{c}{$\begin{array}{c}\text { Electrical conductivity } \\
\left(\mu \mathrm{S} \mathrm{cm}^{-1}\right)\end{array}$} \\
\cline { 2 - 3 } & $\begin{array}{c}\text { Before } \\
\text { distillation }\end{array}$ & $\begin{array}{r}\text { After } \\
\text { distillation }\end{array}$ \\
\hline Rainwater & 14 & 23 \\
Freshly dug well water & 162 & 35 \\
River water & 125 & 60 \\
Heavily polluted dirty water & 238 & 22 \\
WHO standard & $0-800 \mu \mathrm{S} \mathrm{cm}^{-1}$ \\
\hline
\end{tabular}

substance; Cengel and Ghajar, 2002). Details of this are not explored in this research.

\subsection{Laboratory examination of the water samples before and after desalination (quality of the distillates from the raw water samples)}

Table 1 shows the results of the water analyses conducted before and after the solar distillation process. Observation shows that water quality lies within the acceptable range for good and drinkable water, according to WHO prescription for EC. Also, the physical appearance of the distillate/desalinated water shows good turbidity (water looks clear and colourless), which is appealing for human consumption. Also, the repulsive and the irritating odour of the heavily polluted water was drastically reduced.

\subsection{Comparison of the distillate yield in the present study against those which exist in the literature}

Several authors have worked on solar stills of different configurations. Table 2 shows the comparison of the performance evaluation of earlier results and the results of the present study. With the understanding that the performance of any solar still is dependent on the location under consideration, vis-à-vis the inherent/current climatic and atmospheric condition, diurnal irradiance and other specified experimental conditions; however, it can be noticed that the performance of the solar still in consideration is relatively comparable with those existing in the literature, and in some cases, it has a better performance despite the simple design.

\subsection{Solar still efficiency}

The average of the overall daily efficiencies of the CSS with the flat plate collector and the single slope solar still with flat plate collector are $13.906 \%$ and $16.298 \%$, respectively. This shows an improvement of $14.67 \%$ with the inclusion of the single slope design compared with the conventional type. These values are dependent on the weather, climate and the atmospheric conditions with the diurnal irradiance coupled with the still design; hence, it is difficult to compare with existing designs in the literature.

The daily production efficiency, $\epsilon_{\mathrm{d}}$, of the stills are $15.85 \%$ and $26.25 \%$, respectively, for the CSS with flat plate collector and the single slope solar still with flat plate collector.

\subsection{Cost}

It is important to estimate the cost of the solar still for the purpose of improvement in terms of both production and efficiency. Kabeel et al. (2014b) listed the running and capital costs that affect the cost of the production of a solar still, including the design and size of the unit, climatic condition of the site, the properties of the feed water, the required quality of the distilled water to be produced and the cost of wages for available staff.

The adopted design in this research is tailored towards cost-effective and simple infrastructure produced from locally sourced materials which are readily available, easily produced, operational and maintained. This is ensured so that the set-up can easily be acquired by an average family in the rural areas to make potable water readily accessible.

The solar still in this study is made with locally sourced materials and, at the time of the construction, the average cost is approximately USD 150. The analysis for the cost per litre of distilled water, based on Kabeel et al. (2016), is as follows:

- annual cost (AC) is USD 75;

- annual productivity (M) is $2.396 \mathrm{~kg} \mathrm{~m}^{-2}=874.54 \mathrm{~L} \mathrm{yr}^{-1} \mathrm{~m}^{-2}$;

- cost of distilled water per litre (CPL) is AC / $M$;

- CPL (active) is USD 0.0858 per litre;

- CPL (passive) is USD 0.0831 per litre.

Comparing the cost per litre of distilled water for the present design with earlier designs by Kumar and Tiwari (2009) and Abdallah and Badran (2008), the present design showed a significant reduction in the cost of production and can be adopted by rural communities that have shortage of drinkable water.

\section{Conclusion}

The possibility of using the renewable energy from the Sun to provide potable drinkable water from saline or heavily polluted water in areas where potable water is scarce has been explored, using solar desalination technology. The solar desalination method has been found to be a method that uses renewable energy and is an eco-friendly, readily accessible, affordable, and easy method of purifying water. A single slope rectangular basin was designed and constructed at low 


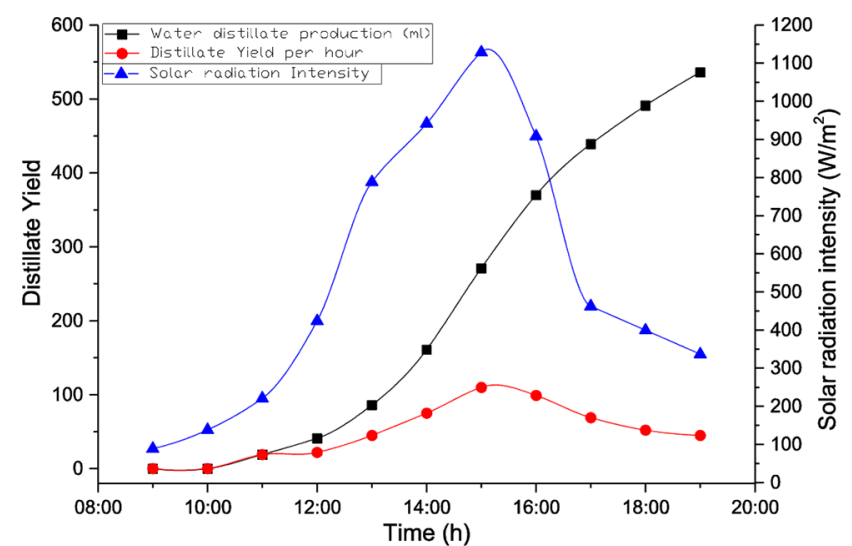

(a)

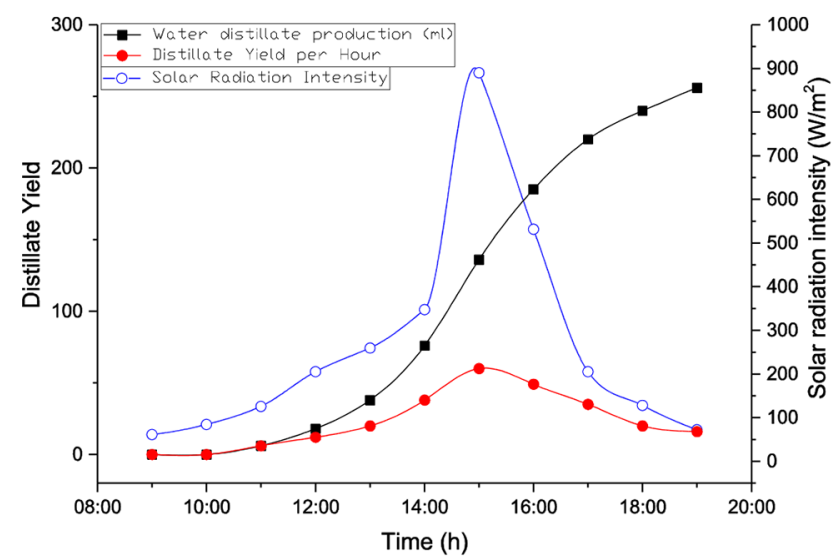

(c)

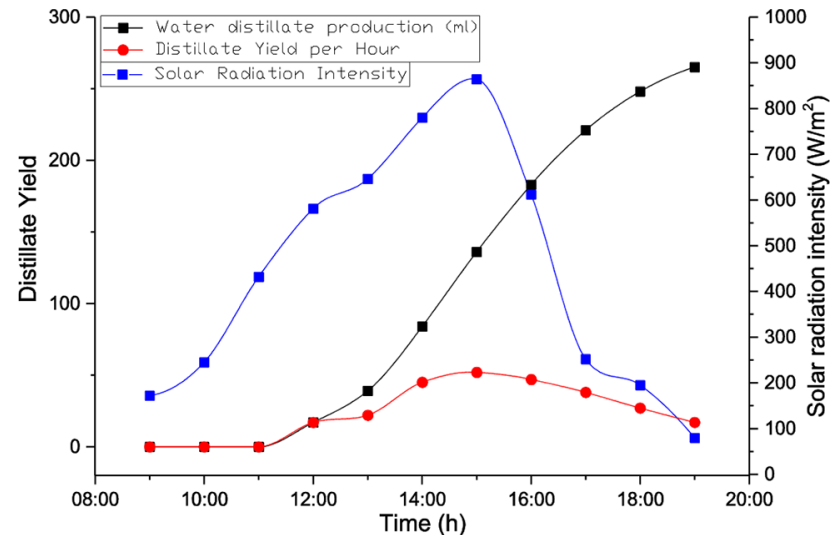

(b)

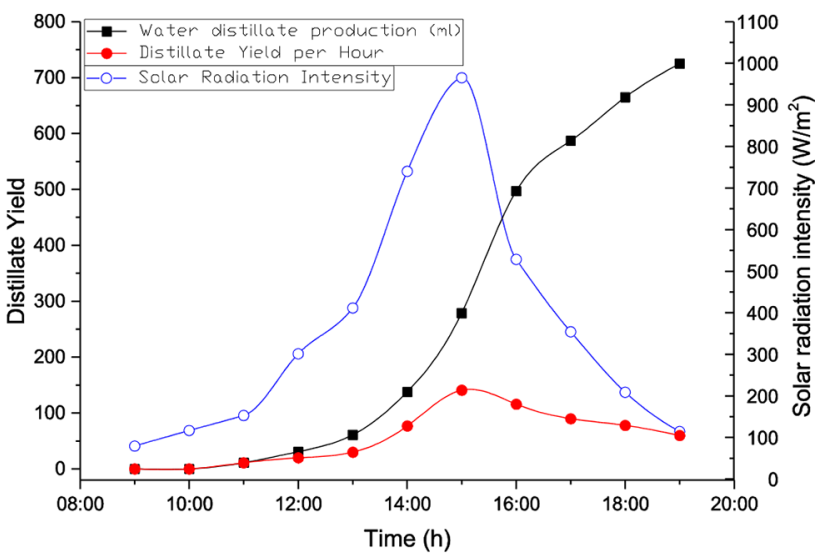

(d)

Figure 5. Influence of solar radiation intensity on the distillate yield. (a) Day 1, (b) day 3, (c) day 6, and (d) day 8 .

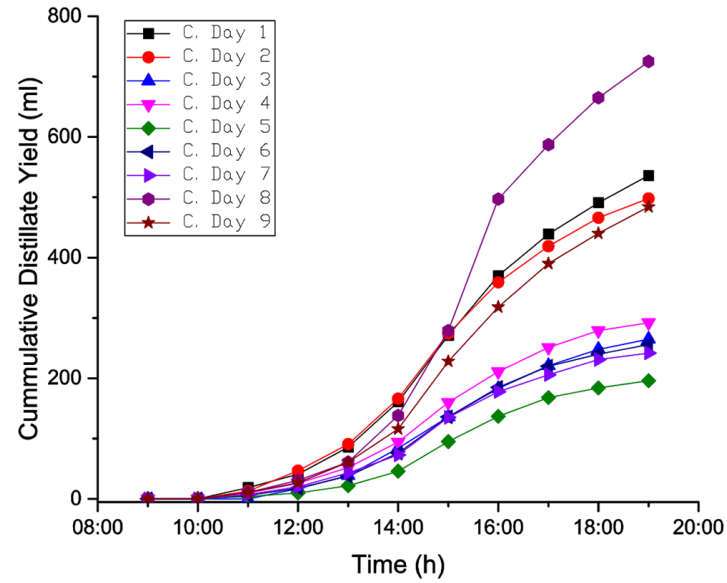

(a)

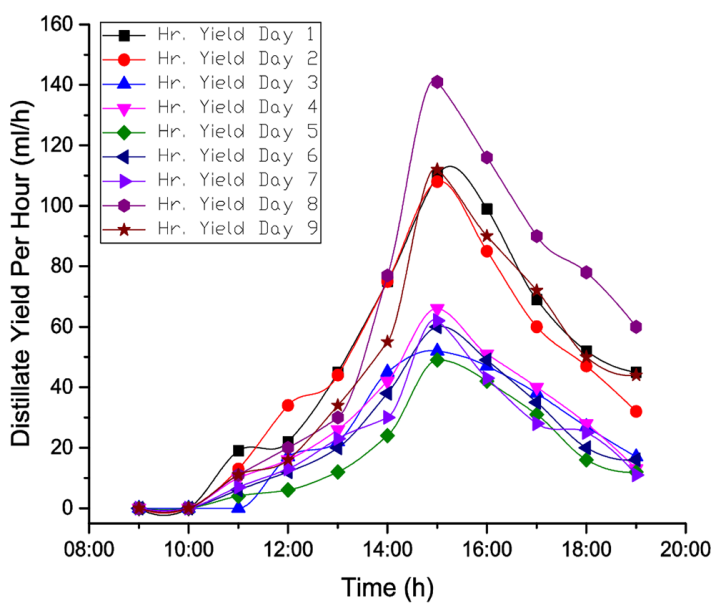

(b)

Figure 6. Distillate yield. (a) Cumulative distillate yield. (b) Distillate yield per hour. 
Table 2. Performance comparison of the solar still in terms of maximum daily productivity.

\begin{tabular}{|c|c|c|c|c|}
\hline No. & Authors & \multicolumn{2}{|l|}{ Type of solar still } & $\begin{array}{l}\text { Maximum daily } \\
\text { productivity }\left(\mathrm{d} \mathrm{m}^{-2}\right)\end{array}$ \\
\hline \multirow[t]{2}{*}{1} & Present study & \multirow{2}{*}{\multicolumn{2}{|c|}{$\begin{array}{l}\text { Active still } \\
\text { Passive still }\end{array}$}} & $2.396 \mathrm{~kg}$ \\
\hline & & & & $1.154 \mathrm{~kg}$ \\
\hline 2 & Voropoulos et al. (2001) & \multicolumn{2}{|l|}{ Still coupled with solar collectors } & $4.2 \mathrm{~kg}$ \\
\hline 3 & Boukar and Harmim (2005) & \multicolumn{2}{|l|}{ One-sided vertical solar still } & $1.4 \mathrm{~kg}$ \\
\hline 4 & Tiwari et al. (2007) & \multicolumn{2}{|l|}{ Flat plate collector } & $0.500 \mathrm{~kg}$ \\
\hline 5 & Tarawneh (2007) & \multicolumn{2}{|l|}{ Conventional still } & $0.720 \mathrm{~kg}$ \\
\hline \multirow[t]{2}{*}{6} & \multirow{2}{*}{ Badran and Abu-khader (2007) } & \multirow[t]{2}{*}{ Single slope solar still } & $3.5 \mathrm{~cm}$ depth & $0.590 \mathrm{~kg}$ \\
\hline & & & $2.0 \mathrm{~cm}$ depth & $0.800 \mathrm{~kg}$ \\
\hline 7 & Velmurugan et al. (2008) & Solar still with fin & & $0.425 \mathrm{~kg}$ \\
\hline 8 & Abdallah and Badran (2008) & Fixed and tracking solar stills & & $0.175 \mathrm{~kg}$ \\
\hline \multirow[t]{3}{*}{9} & \multirow[t]{3}{*}{ Singh et al. (2011) } & \multirow{3}{*}{$\begin{array}{l}\text { Hybrid photovoltaic thermal (PVT) } \\
\text { double slope active solar still }\end{array}$} & Series & $1.07 \mathrm{~kg}$ \\
\hline & & & Parallel & $1.30 \mathrm{~kg}$ \\
\hline & & & Natural & $0.90 \mathrm{~kg}$ \\
\hline \multirow[t]{7}{*}{10} & Omara et al. (2013) & \multirow{7}{*}{\multicolumn{2}{|c|}{$\begin{array}{l}\text { Conventional } \\
\text { Single layer lined wick } \\
\text { Single layer square wick } \\
\text { Double layer lined wick } \\
\text { Concentrating collector } \\
\text { Evacuated tube collector } \\
\text { Evacuated tube collector with heat pipe }\end{array}$}} & $0.44 \mathrm{~kg}$ \\
\hline & & & & $1.00 \mathrm{~kg}$ \\
\hline & & & & $1.10 \mathrm{~kg}$ \\
\hline & & & & $0.78 \mathrm{~kg}$ \\
\hline & & & & $0.6 \mathrm{~kg}$ \\
\hline & & & & $0.64 \mathrm{~kg}$ \\
\hline & & & & $0.70 \mathrm{~kg}$ \\
\hline \multirow[t]{3}{*}{11} & Ahsan et al. (2013) & \multirow[t]{3}{*}{ Triangular solar still } & $1.5 \mathrm{~cm}$ depth & $0.04 \mathrm{~kg}$ \\
\hline & & & $2.5 \mathrm{~cm}$ depth & $0.05 \mathrm{~kg}$ \\
\hline & & & $5.0 \mathrm{~cm}$ depth & $0.033 \mathrm{~kg}$ \\
\hline 12 & Gorjian et al. (2014) & \multicolumn{2}{|c|}{ Stand-alone point-focus parabolic solar still } & $1.07 \mathrm{~kg}$ \\
\hline \multirow[t]{2}{*}{13} & Omara et al. (2014) & \multirow{2}{*}{\multicolumn{2}{|c|}{$\begin{array}{l}\text { Stepped solar still } \\
\text { Conventional }\end{array}$}} & $1.18 \mathrm{~kg}$ \\
\hline & & & & $0.65 \mathrm{~kg}$ \\
\hline 14 & Elango and Murugavel (2015) & \multicolumn{2}{|l|}{ Double basin stills } & $0.525 \mathrm{~kg}$ \\
\hline \multirow[t]{2}{*}{15} & Sathyamurthy et al. (2015) & \multirow{2}{*}{\multicolumn{2}{|c|}{$\begin{array}{l}\text { Still without phase change material (PCM) } \\
\text { Still with PCM }\end{array}$}} & $0.22 \mathrm{~kg}$ \\
\hline & & & & $0.12 \mathrm{~kg}$ \\
\hline 16 & El-Agouz et al. (2015) & \multicolumn{2}{|l|}{ Continuous flow inclined solar still } & $0.6 \mathrm{~kg}$ \\
\hline \multirow[t]{4}{*}{17} & T. Elango et al. (2015) & Single slope solar still with different & Water & $0.092 \mathrm{~kg}$ \\
\hline & & water nanofluids & Water $+\mathrm{Al}_{2} \mathrm{O}_{3}$ & $0.160 \mathrm{~kg}$ \\
\hline & & & Water $+\mathrm{ZnO}$ & $0.125 \mathrm{~kg}$ \\
\hline & & & Water $+\mathrm{SnO}_{2}$ & $0.132 \mathrm{~kg}$ \\
\hline 18 & Kumar and Rajesh (2016) & \multicolumn{2}{|l|}{ Hybrid still } & $0.62 \mathrm{~kg}$ \\
\hline 19 & Faegh and Behshad (2017) & Solar still with PCM & & $1.03 \mathrm{~kg}$ \\
\hline \multirow[t]{3}{*}{20} & Panchal and Mohan (2017) & Conventional solar still & & $0.390 \mathrm{~kg}$ \\
\hline & & Circular fin solar still & & $0.520 \mathrm{~kg}$ \\
\hline & & Square fin solar still & & $0.590 \mathrm{~kg}$ \\
\hline
\end{tabular}


cost, using lightweight and available locally sourced materials. The effects of solar radiation intensity, ambient temperature, condensing inner glass cover temperature, water temperature and absorber temperature on the water distillate yield from the solar still were observed based on the climatic condition of Ile-Ife, Nigeria. Results show the direct relationship between and huge dependency of solar still daily distillate yield on the solar radiation intensity and the temperature difference between the condensing inner glass cover and the water. A high distillate yield was recorded when the solar radiation intensity was at its peak, accompanied with temperature increases for all of the solar still components at the same time of the day. The temperatures increased as the solar radiation intensity increased; however, a larger increase was experienced for water and the absorber in the basin, which was primarily due to the heat-retaining property of the black body used. The wind speed of the research station also was a contributing factor to the drop in the glass temperature, hence constituting a huge temperature difference between the condensing inner glass cover and the water for a higher heat transfer and evaporation rate and a larger distillate yield. The impact of the flat plate collector on the distillate yield was also investigated. The incorporation of the flat plate collector produced a higher distillate yield. The preheated water it supplied created a huge temperature difference between the condensing inner glass cover and the water which, consequently, produced more distillate yield compared to a solar still without flat plate collector. The desalination product quality was analysed based on its EC and the amount of total dissolved solids present in it. The distilled water was found to be within the acceptable range for drinkable water according to the World Health Organization standards and guidelines. This shows the potential of water desalination using solar energy, especially in areas where waterborne diseases are imminent due to the scarcity of potable drinkable water. It could be predicted from the trends in the results that the distillate yield would be higher during the dry season, which is characterized by higher solar radiation intensity, compared to the solar radiation intensity recorded during the rainy season, which is when the experiment was performed.

Data availability. Data obtained have been used in the main body of the article. However, these data can also be accessed at https: //osf.io/bqdnx/ (Adio, 2021).

Author contributions. SAA conceived the idea, defined the problem statement, was the main supervisor on the project and did several rounds of reviews during the writing stage of the paper. EAO led the experimental set-up, data collection and wrote the introduction, literature review and the cost analysis section. AOM was one of the project co-supervisors and worked on the problem definition and several rounds of reviews during the writing stage of the paper. AAF assisted with the experimental set-up and data collection and also worked on the data analysis and graphical representations. KTO co- supervised the project and worked on the experimental design and results interpretations. SOO also supervised the project during the experimental set-up and data collection and reviewed the first draft of the paper. POF participated in the experimental set-up and data collection and did some initial writing of the paper.

Competing interests. The authors declare that they have no conflict of interest.

Review statement. This paper was edited by Luuk Rietveld and reviewed by Bas Heijman and one anonymous referee.

\section{References}

Abbasi, T. and Abbasi, S. A.: Sources of Pollution in Rooftop Rainwater Harvesting Systems and Their Control, Crit. Rev. Env. Sci. Tec., 41, 2097-2167, https://doi.org/10.1080/10643389.2010.497438, 2011.

Abdallah, S. and Badran, O. O.: Sun tracking system for productivity enhancement of solar still, Desalination, 220, 669-676, https://doi.org/10.1016/j.desal.2007.02.047, 2008.

Adio, S. A.: Solar Distillation of Impure Water from Four Different Water Sources under South-Western Nigeria Climate-Raw Data, OSF, available at: https://osf.io/bqdnx/, last access: 9 February 2021.

Ahmadi, G., Toghraie, D., and Akbari, O. A.: Solar parallel feed water heating repowering of a steam power plant: A case study in Iran, Renew. Sust. Energ. Rev., 77, 474-485, https://doi.org/10.1016/j.rser.2017.04.019, 2017.

Ahsan, A., Imteaz, M., Thomas, U. A., Azmi, M., Rahman, A., and Nik Daud, N. N.: Parameters affecting the performance of a low cost solar still, Appl. Energ., 114, 924-930, https://doi.org/10.1016/j.apenergy.2013.08.066, 2013.

Ali, A. I., Eze, U. E., Onyeneho, K. C., Eng, I. C. I. M., and View, I.: Design of Single Effect Solar Still for Water Purification, Pacific J. Sci. Technol., 20, 19-26, 2019.

Asbik, M., Ansari, O., Bah, A., Zari, N., Mimet, A., and El-ghetany, H.: Exergy analysis of solar desalination still combined with heat storage system using phase change material (PCM), Desalination, 381, 26-37, https://doi.org/10.1016/j.desal.2015.11.031, 2016.

Badran, O. O. and Abu-khader, M. M.: Evaluating thermal performance of a single slope solar still, Heat Mass Transfer, 43, 985995, https://doi.org/10.1007/s00231-006-0180-0, 2007.

Bahadori, M. N. and Edlin, F. E.: Improvement of solar stills by the surface treatment of glass, Sol. Energy, 14, 339-352, 1973.

Bennamoun, L., Arlabosse, P., and Léonard, A.: Review on fundamental aspect of application of drying process to wastewater sludge, Renew. Sust. Energ. Rev., 28, 29-43, https://doi.org/10.1016/j.rser.2013.07.043, 2013.

Boukar, M. and Harmim, A.: Performance evaluation of a one-sided vertical solar still tested in the Desert of Algeria, Desalination, 183, 113-126, 2005.

Cengel, Y. A. and Boles, M. A.: Thermodynamics: an engineering approach, McGraw Hill, New York, USA, p. 712, 2015. 
Cengel, Y. A. and Ghajar, A. J.: Heat and mass transfer (a practical approach), McGraw Hill, New York, USA, 561-607, 2002.

Chinnery, D. N. W.: Solar water heating in South Africa, Counc. Sci. Ind. Res., 248, 1-79, 1971.

Cowling, T. G.: Atmospheric absorption of heat radiation by water vapour, London, Edinburgh, Dublin Philos. Mag. J. Sci., 41, 109$123,1950$.

Delgado-Torres, A. M., Garcia-Rodriguez, L., and Romero-Ternero, V. J.: Preliminary design of a solar thermal-powered seawater reverse osmosis system, Desalination, 216, 292-305, 2007.

Edeoja, A. O., Unom, F., and Edeoja, J. A.: Investigation of the Effect of Cover Thickness on the Yield of a Single Basin Solar Still under Makurdi Climate, Int. J. Eng. Sci. Invent., 14, 131138, 2015.

El-Agouz, S. A., El-Samadony, Y. A. F., and Kabeel, A. E.: Performance evaluation of a continuous flow inclined solar still desalination system, Energ. Convers. Manage., 101, 606-615, https://doi.org/10.1016/j.enconman.2015.05.069, 2015.

El-Samadony, Y. A. F., El-Maghlany, W. M., and Kabeel, A. E.: In fluence of glass cover inclination angle on radiation heat transfer rate within stepped solar still, Desalination, 384, 68-77, https://doi.org/10.1016/j.desal.2016.01.031, 2016.

El-Sebaii, A. A.: Effect of wind speed on some designs of solar stills, Energ. Convers. Manage., 41, 523-538, 2000.

El-Sebaii, A. A.: Effect of wind speed on active and passive solar stills, Energ. Convers. Manage., 45, 1187-1204, 2004.

Elango, C., Gunasekaran, N., and Sampathkumar, K.: Thermal models of solar still - A comprehensive review, Renew. Sust. Energ. Rev., 47, 856-911, https://doi.org/10.1016/j.rser.2015.03.054, 2015.

Elango, T. and Murugavel, K. K.: The effect of the water depth on the productivity for single and double basin double slope glass solar stills, Desalination, 359, 82-91, https://doi.org/10.1016/j.desal.2014.12.036, 2015.

Elango, T., Kannan, A., and Murugavel, K. K.: Performance study on single basin single slope solar still with different water nano fluids, Desalination, 360, 45-51, https://doi.org/10.1016/j.desal.2015.01.004, 2015.

Elsayed, M. M.: Optimum orientation of absorber plates, Sol. Energy, 42, 89-102, 1989.

Faegh, M. and Behshad, M.: Experimental investigation of a solar still equipped with an external heat storage system using phase change materials and heat pipes, Desalination, 409, 128-135, https://doi.org/10.1016/j.desal.2017.01.023, 2017.

Felske, J. D.: The effect of off-south orientation on the performance of flat-plate solar collectors, Sol. Energy, 20, 29-36, https://doi.org/10.1016/0038-092X(78)90138-X, 1978.

Garg, H. P. and Mann, H. S.: Effect of climatic, operational and design parameters on the year round performance of singlesloped and double-sloped solar still under Indian arid zone conditions, Sol. Energy, 8, 159-163, https://doi.org/10.1016/0038092X(76)90052-9, 1976.

González, A. C.: Study to analyze the viability of rainwater catchment from roofs for its reuse in Tegucigalpa, Honduras, 20002019-CSU, Master Thesis Dissertation, Department of Civil and Environmental Engineering, Colorado State University, Fort Collins, CO, USA, 2012.

Goosen, M., Mahmoudi, H., and Ghaffour, N.: Overview of renewable energy technologies for freshwater production, in: Renew- able Energy Applications For Freshwater Production, edited by: Bundschuh, J. and Hoinkis, J., CRS Press and IWA Publishing, London, UK, 25-77, 2012.

Gorjian, S., Ghobadian, B., Hashjin, T. T., and Banakar, A.: Experimental performance evaluation of a stand-alone point-focus parabolic solar still, Desalination, 352, 1-17, https://doi.org/10.1016/j.desal.2014.08.005, 2014.

Heywood, H.: Operating experiences with solar water heating, Inst. Heat. Vent. Eng. J., 39, 63-69, 1971.

Kabeel, A. E., Khalil, A., Omara, Z. M., and Younes, M. M.: Theoretical and experimental parametric study of modi fi ed stepped solar still, Desalination, 289, 12-20, https://doi.org/10.1016/j.desal.2011.12.023, 2012.

Kabeel, A. E., Omara, Z. M., and Essa, F. A.: Enhancement of modified solar still integrated with external condenser using nanofluids: An experimental approach, Energ. Convers. Manage., 78, 493-498, https://doi.org/10.1016/j.enconman.2013.11.013, $2014 a$.

Kabeel, A. E., Omara, Z. M., and Essa, F. A.: Improving the performance of solar still by using nanofluids and providing vacuum, Energ. Convers. Manage., 86, 268-274, https://doi.org/10.1016/j.enconman.2014.05.050, 2014b.

Kabeel, A. E., Omara, Z. M., Essa, F. A., and Abdullah, A. S.: Solar still with condenser - A detailed review, Renew. Sust. Energ. Rev., 59, 839-857, https://doi.org/10.1016/j.rser.2016.01.020, 2016.

Kalogirou, S. A.: Concentrating solar power plants for electricity and desalinated water production, World Renewable Energy Congress, 8-13 May 2011, Linköping, Sweden, 3881-3888, https://doi.org/10.3384/ecp110573881, 2011.

Kalogirou, S. A.: Solar energy engineering: processes and systems, Academic Press, San Diego, USA, 2014.

Kalogirou, S. A., Karellas, S., Braimakis, K., and Stanciu, C.: Exergy analysis of solar thermal collectors and processes, Prog. Energ. Combust., 56, 106-137, https://doi.org/10.1016/j.pecs.2016.05.002, 2016.

Khorasanizadeh, H., Mohammadi, K., and Mostafaeipour, A.: Establishing a diffuse solar radiation model for determining the optimum tilt angle of solar surfaces in Tabass, Iran, Energ. Convers. Manage., 78, 805-814, https://doi.org/10.1016/j.enconman.2013.11.048, 2014.

Kumar, K. V. and Bai, R. K.: Performance study on solar still with enhanced condensation, Desalination, 230, 51-61, 2008.

Kumar, M. A. and Rajesh, S.: Performance evaluation of a solar still coupled to an evacuated tube collector type solar water heater, Int. J. Mech. Eng. Technol., 7, 11-25, 2016.

Kumar, S. and Tiwari, G. N.: Life cycle cost analysis of single slope hybrid (PV/T) active solar still, Appl. Energy, 86, 1995-2004, https://doi.org/10.1016/j.apenergy.2009.03.005, 2009.

Lye, D. J.: Rooftop runoff as a source of contamination: a review, Sci. Total Environ., 407, 5429-5434., 2009.

Manabe, S. and Wetherald, R. T.: Thermal equilibrium of the atmosphere with a given distribution of relative humidity, J. Atmos. Sci., 24, 241-259, 1967.

Manokar, A. M., Murugavel, K. K., and Esakkimuthu, G.: Different parameters affecting the rate of evaporation and condensation on passive solar still - A review, Renew. Sust. Energ. Rev., 38, 309322, https://doi.org/10.1016/j.rser.2014.05.092, 2014. 
Meera, V. and Ahammed, M. M.: Water quality of rooftop rainwater harvesting systems: a review, J. Water Supply Res. T., 55, 257268, 2006

Mendez, C. B., Afshar, B. R., Kinney, K., Barrett, M. E., and Kirisits, M. J.: Effect of roof material on water quality for rainwater harvesting systems, Texas Water Dev. Board, Austin, Texas, USA, 2010.

Morad, M. M., El-Maghawry, H. A. M., and Wasfy, K. I.: Improving the double slope solar still performance by using flat-plate solar collector and cooling glass cover, Desalination, 373, 1-9, https://doi.org/10.1016/j.desal.2015.06.017, 2015.

Muftah, A. F., Alghoul, M. A., Fudholi, A., and Sopian, K.: Factors affecting basin type solar still productivity: A detailed review, Renew. Sust. Energ. Rev., 32, 430-447, https://doi.org/10.1016/j.rser.2013.12.052, 2014.

Murugavel, K. K., Sivakumar, S., Ahamed, J. R., Chockalingam, K. K. S. K., and Srithar, K.: Single basin double slope solar still with minimum basin depth and energy storing materials, Appl. Energy, 87, 514-523, 2010.

Nafey, A. S., Abdelkader, M., Abdelmotalip, A., and Mabrouk, A. A.: Parameters affecting solar still productivity, Energy Conversion Management, 41, 1797-1809, https://doi.org/10.1016/S0196-8904(99)00188-0, 2000.

Norman, M., Shafri, H. Z., Mansor, S. B., and Yusuf, B.: Review of remote sensing and geospatial technologies in estimating rooftop rainwater harvesting (RRWH) quality, Int. Soil Water Conserv. Res., 7, 266-274, 2019.

Omara, Z. M., Eltawil, M. A., and Elnashar, E. A.: A new hybrid desalination system using wicks/solar still and evacuated solar water heater, Desalination, 325, 56-64, https://doi.org/10.1016/j.desal.2013.06.024, 2013.

Omara, Z. M., Kabeel, A. E., and Younes, M. M.: Enhancing the stepped solar still performance using internal and external reflectors, Energ. Convers. Manage., 78, 876-881, https://doi.org/10.1016/j.enconman.2013.07.092, 2014

Onwujekwe, O., Uzochukwu, B., Dike, N., Uguru, N., Nwobi, E., and Shu, E.: Malaria treatment perceptions, practices and influences on provider behaviour: comparing hospitals and non-hospitals in south-east Nigeria, Malaria J., 8, 246, https://doi.org/10.1186/1475-2875-8-246, 2009.

Onyegegbu, S. O.: Nocturnal distillation in basin-type solar stills, Appl. Energy, 24, 22-29, 1986.

Ozuomba, J. O., Emmanuel, A., Ozuomba, C. U., and Udoye, M. C.: Design and Determination of the Efficiency of a SlantingType Solar Water Distillation Kit, Niger. J. Technol., 36, 643647, 2017.

Panchal, H. and Mohan, I.: Various methods applied to solar still for enhancement of distillate output, Desalination, 415, 76-89, https://doi.org/10.1016/j.desal.2017.04.015, 2017.

Qiu, G. and Riffat, S. B.: Optimum tilt angle of solar collectors and its impact on performance, Int. J. Ambient Energy, 24, 13-20, https://doi.org/10.1080/01430750.2003.9674898, 2003.

Rab, M. A., Bile, M. K., Mubarik, M. M., Asghar, H., Sami, Z., Siddiqi, S., and Burney, M. I.: Water-borne hepatitis E virus epidemic in Islamabad, Pakistan: a common source outbreak traced to the malfunction of a modern water treatment plant, Am. J. Trop. Med. Hyg., 57, 151-157, 1997.

Rahbar, N., Abolfazli, J., and Fotouhi-bafghi, E.: ScienceDirect Estimation of convective heat transfer coefficient and water-productivity in a tubular solar still - CFD simulation and theoretical analysis, Sol. Energy, 113, 313-323, https://doi.org/10.1016/j.solener.2014.12.032, 2015.

Sampathkumar, K., Arjunan, T. V, Pitchandi, P., and Senthilkumar, P.: Active solar distillation - A detailed review, 14, 1503-1526, https://doi.org/10.1016/j.rser.2010.01.023, 2010.

Sathyamurthy, R., El-Agouz, S. A., and Dharmaraj, V.: Experimental analysis of a portable solar still with evaporation and condensation chambers, Desalination, 367, 180-185, https://doi.org/10.1016/j.desal.2015.04.012, 2015.

Sharshir, S. W., Yang, N., Peng, G. and Kabeel, A. E.: Factors affecting solar stills productivity and improvement techniques: a detailed review, App. Therm. Eng., 100, 267-284, https://doi.org/10.1016/j.applthermaleng.2015.11.041, 2016.

Singh, G., Kumar, S., and Tiwari, G. N.: Design, fabrication and performance evaluation of a hybrid photovoltaic thermal (PVT) double slope active solar still, Desalination, 277, 399-406, https://doi.org/10.1016/j.desal.2011.04.064, 2011.

Sivakumar, V. and Sundaram, E. G.: Improvement techniques of solar still efficiency: A review, Renew. Sust. Energ. Rev., 28, 246264, https://doi.org/10.1016/j.rser.2013.07.037, 2013.

Smith, S. I., Odunukwe, N. N., Niemogha, M. T., Ahmed, A. O., Efienemokwu, C. A., Otuonye, M. N., and Idigbe, E. O.: Diagnostic methods for typhoid fever in Nigeria, Br. J. Biomed. Sci., 61, 179-181, 2004.

Stanciu, C. and Stanciu, D.: Optimum tilt angle for flat plate collectors all over the World - A declination dependence formula and comparisons of three solar radiation models, Energ. Convers. Manage., 81, 133-143, https://doi.org/10.1016/j.enconman.2014.02.016, 2014.

Stonebraker, A., Newmeyer, J., and Branner, M.: Parabolic Solar Water Distillation, Sr. Des. Proj. Interim report. Dep. Mech. Eng. SDSU Coll. Eng., Department of Mechancal Engineering, San Diego State University, San Diego, USA, 1-45, 2010.

Taghvaei, H., Taghvaei, H., Jafarpur, K., Feilizadeh, M., and Estahbanati, M. R. K.: Experimental investigation of the effect of solar collecting area on the performance of active solar stills with different brine depths, Desalination, 358, 76-83, https://doi.org/10.1016/j.desal.2014.11.032, 2015.

Tarawneh, M. S. K.: Effect of Water Depth on the Performance Evaluation of Solar Still, Jordan J. Mech. Ind. Eng., 1, 23-29, 2007.

Tiwari, A. K. and Tiwari, G. N.: Effect of inclination of condensing cover and water depth in solar still for maximum yield: In winter climatic condition, ASME Int. Mech. Eng. Congr. Expo., IMECE2005-82690, 395-407, https://doi.org/10.1115/IMECE2005-82690, 2005.

Tiwari, A. K. and Tiwari, G. N.: Effect of water depths on heat and mass transfer in a passive solar still: in summer climatic condition, Desalination, 195, 78-94, 2006.

Tiwari, A. K. and Tiwari, G. N.: Effect of cover inclination and water depth on performance of a solar still for Indian climatic conditions, J. Sol. Energy Eng., 130, 024502, https://doi.org/10.1115/1.2844450, 2008.

Tiwari, G. N., Thomas, J. M., and Khan, E.: Optimisation of glass cover inclination for maximum yield in a solar still, Heat Recov. Syst. CHP, 14, 447-455, https://doi.org/10.1016/08904332(94)90048-5, 1994. 
Tiwari, G. N., Dimri, V., Singh, U., Chel, A., and Sarkar, B.: Comparative thermal performance evaluation of an active solar distillation system, Int. J. Energ. Res., 31, 1465-1482, https://doi.org/10.1002/er.1314, 2007.

Tiwari, G. N., Dimri, V., and Chel, A.: Parametric study of an active and passive solar distillation system: Energy and exergy analysis, Desalination, 242, 1-18, https://doi.org/10.1016/j.desal.2008.03.027, 2009.

University of Texas at Austin: Rainwater harvest study finds roofing material affects water quality, ScienceDaily, Rockville, Maryland, USA, available at: https://www.sciencedaily.com/releases/ 2011/03/110307142229.htm (last access: 4 February 2021), 2011.
Velmurugan, V., Deenadayalan, C. K., Vinod, H., and Srithar, K.: Desalination of effluent using fin type solar still, Energy, 33, 1719-1727, https://doi.org/10.1016/j.energy.2008.07.001, 2008.

Voropoulos, K., Mathioulakis, E., and Belessiotis, V.: Experimental investigation of a solar still coupled with solar collectors, Desalination, 138, 28-31, 2001.

Winfred Rufuss, D. D., Iniyan, S., Suganthi, L., and Pa, D.: Nanoparticles Enhanced Phase Change Material (NPCM) as Heat Storage in Solar Still Application for Productivity Enhancement, Energy Procedia, 141, 45-49, https://doi.org/10.1016/j.egypro.2017.11.009, 2017. 